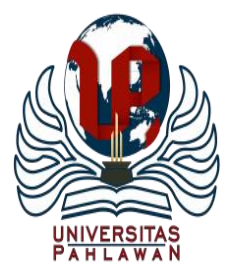

Edukatif : Jurnal Ilmu Pendidikan Volume 3 Nomor 1 Tahun 2021 Halm 165-173

EDUKATIF: JURNAL ILMU PENDIDIKAN

Research \& Learning in Education

https://edukatif.org/index.php/edukatif/index

\title{
Analisis Problema Pembelajaran Daring Terhadap Pendidikan Karakter Peserta Didik
}

\author{
Harri Jumarto Suriadi ${ }^{1 凶}$, Firman $^{2}$, Riska Ahmad ${ }^{3}$ \\ Universitas Negeri Padang, Sumatera Barat, Indonesia ${ }^{1,2,3}$ \\ E-mail : $\underline{\text { harrijumarto19021996@ gmail.com }}{ }^{1}, \underline{\text { firman@konselor.org.com }}^{2}, \underline{\text { ra5402945@ gmail.com }}^{3}$
}

\begin{abstract}
Abstrak
Pendidikan karakter merupakan perwujudan dalam mencapai generasi yang cerdas dan mampu memiliki akhlak dan kepribadian yang berguna bagi bangsa Indonesia. Suksesnya pendidikan dilihat dari seberapa besar karakter mereka ketika bisa menyeimbangkan kognitif, afektif dan psikomotornya untuk menjadi manusia yang sempurna. Pada tahun 2020 telah terjadi pandemi Covid - 19 yang menyebabkan semuanya berubah pembelajaran yang dilaksanakan disekolah berubah sesuai dengan aturan pemerintah dilaksanakan dirumah dengan daring atau belajar dengan jarak jauh. Penelitian yang dilakukan sekarang ialah deskriptif kualitatif dengan studi literatur yang berusaha memberikan gambaran solusi permasalahan pembelajaran daring terhadap pendidikan karakter peserta didik di sekolah menengah pertama. Naskah ini menampilkan problema pembelajaran daring, dampak pembelajaran daring terhadap pendidikan karakter peserta didik, solusi dan pemecahan masalah. Penelitian ini memakai studi pustaka / studi literatur, dengan mengkaji dari beberapa hasil penelitian, artikel, ebook dan studi kasus yang terjadi dilapangan.
\end{abstract}

Kata Kunci: Belajar Daring, Pendidikan karakter, Peserta didik.

\begin{abstract}
Character education is a manifestation of reaching a generation that is smart and capable of having useful morals and personalities for the Indonesian nation. The success of education is seen from how big their character is when they can balance their cognitive, affective and psychomotor to become the perfect human being. In 2020 there has been a Covid - 19 pandemic which has caused everything to change, learning carried out in schools has changed according to government regulations carried out at home online or learning remotely. The research that is currently being carried out is descriptive qualitative with literature studies that attempt to provide an overview of the solutions to online learning problems to character education for students in junior high schools. This manuscript presents online learning problems, the impact of online learning on character education of students, solutions and problem solving. This research uses literature study / literature study, by examining several research results, articles, ebooks and case studies that occur in the field.
\end{abstract}

Keywords: Online Learn, character building, Students.

Copyright (c) 2021 Harri Jumarto Suriadi, Firman, Riska Ahmad

$\triangle$ Corresponding author

Email : harrijumarto19021996@gmail.com

DOI : https://doi.org/10.31004/edukatif.v3i1.251

ISSN 2656-8063 (Media Cetak)

ISSN 2656-8071 (Media Online) 


\section{PENDAHULUAN}

Pendidikan ialah proses pembelajaran dengan tujuan untuk dikembangkannya bakat pada diri anak, baik itu bersifat kepribadian, kecerdasan, spritual dan keagamaan. (Juliya and Herlambang, 2021). Pendidikan dapat pula diartikan sebagai upaya sadar yang sistematis dalam mencapai kehidupan yang lebih baik. Secara sederhana, pendidikan merupakan pelajaran yang beharga bagi anak yang membuatnya menjadi manusia yang lebih kritis dalam berpikir sehingga bisa menciptakan karakter yang di inginkan oleh guru dan kedua orang tua mereka. Sejalan dengan itu (Defi, 2020) Begitu krusialnya kedudukan karakter dalam proses pembelajaran membuat guru harus benar-benar mampu menyentuh sampai ke akar-akarnya perihal karakter ini, yang tercakup dalam proses pembelajaran yang sudah dicanangkan oleh guru yang bersangkutan sesuai dengan definisi pendidikan menurut UU No. 20 Tahun tentang sistem pendidikan nasional yakni, Pendidikan adalah usaha sadar dan terencana untuk mewujudkan suasana belajar dan proses pembelajaran agar peserta didik secara aktif mengembangkan potensi dirinya untuk memiliki kekuatan spiritual keagamaan, pengendalian diri, kepribadian, kecerdasan, akhlak mulia, serta keterampilan yang diperlukan dirinya, masyarakat, bangsa dan negara.

Penelitian yang dilakukan oleh (Absor, 2020) didapatkan hasil bahwa guru juga harus sadar untuk menanamkan nilai karakter harus dilakukan secara tersirat (kurikulum tersembunyi), sehingga hasil pembelajarannya tidak bisa dilakukan dengan instan. Berarti diharapkan peluang yang muncul diberikan dengan pembelajaran yang menarik sehingga dapat memperbaiki karakter dari peserta didik tersebut. Permasalahan berikutnya terdapat di penelitian (Nafisah and Zafi, 2020) terdapat penurunan karakter bagi peserta didik dimasa pandemi, karena dalam pendidikan karakter di masa pandemi covid 19 harus memperhatikan dasar pengembangan karakter itu sendiri yakni, perkembangan kognitif, perkembangan sosial, dan perkembangan moral peserta didik.

Pendidikan Karakter merupakan harapan sebuah negara terhadap bangsanya, di mana pendidikan karakter akan melahirkan peserta didik yang sangat diharapkan, dimana peserta didik tersebut bisa mengimbangkan sikap kognitif, afektif dan psikomotoriknya sehingga peserta didik tersebut bisa bersaing nantinya ketika mereka sudah tumbuh dewasa. (Astamal, Firman, 2021) pendidikan karakter merupakan usaha yang sadar untuk merubah dan mengembangkan perilaku seseorang kearah yang lebih baik agar mampu hidup dalam bermasyarakat dan bisa bergabung didalam kehidupan bermasyarakat nantinya sehingga peserta didik tersebut tidak terpengaruh oleh hal-hal yang buruk nantinya, sejalan dengan itu (Wandari and Nugraha, 2021) Pendidikan sebagai suatu proses yang bergerak, dalam artian bisa merubah diri dan berkembang ketika terjadi permasalahan di masyarakat sehingga peserta didik tersebut bisa mengikuti perubahan zaman nantinya dan tidak tertinggal oleh perkembangan zaman. menurut (Sudarsana, 2015) pendidikan disekolah sebagai tempat pendidikan diselenggarakan untuk generasi muda berkembang, sehingga peserta didik dapat dengan aktif mengeluarkan sesuatu yang ada pada dirinya yang orang lain tidak ketahui sama sekali.

Dari beberapa pendapat diatas dapat diatik kesimpulan bahwa pendidikan merupakan usaha sadar untuk merubah tingkah laku seseorang ke arah yang lebih baik dan dapat mengikuti perubahan yang terjadi dimasyarakat dan bisa mengikuti perkembangan zaman, peserta didik seperti itulah yang diharapkan nantinya sehingga mereka ketika sudah tumbuh dewasa nanti bisa menjadi manusia yang berguna bagi bangsa dan negara serta menjadi kebanggaan dari kedua orang tua mereka.

Pandemi Global Corona (COVID 19) yang terjadi didunia merupakan masalah global yang terjadi didunia dan mengakibatkan perubahan besar terjadi dalam kehidupan, salah satunya di Indonesia yang mengakibatkan situasi berubah secara drastis, yang awalnya masyarakat bisa hidup normal dan saling berinteraksi secara langsung namun sekarang semua berubah menjadi serba online atau daring termasuk dibidang pendidikan. Corona Disease Virus 19 (COVID-19) membuat pemerintah mengeluarkan kebijakan 
167 Analisis Problema Pembelajaran Daring Terhadap Pendidikan Karakter Peserta Didik - Harri Jumarto, Firman, Riska Ahmad

DOI : https://doi.org/10.31004/edukatif.v3i1.251

sosial distancing, kita tidak diperbolehkan berkumpul dengan orang dan tidak bisa berdekatan atau menjaga jarak fisik (physical distancing) dalam mencegah tersebarnya virus corona.

Permasalahan terjadi dikarenakan Covid - 19 merupakan hasil dari ketidakpatuhan yang terjadi dikalangan masyarakat dengan diberlakukannya lockdown yang berdampak terhadap kehidupan masyarakat dan dari ketidakpatuhan tersebut dengan menjaga diri di masa pandemi dan terlalu mementingkan diri pribadi dan melanggar peraturan, orang yang tidak menganjurkan peraturan tersebut untuk PSBB memperlihatkan karakter tidak perduli dengan lingkungannya (Sudarsana, 2015), sehingga dengan ketidakpatuhan tersebut mengakibatkan virus corona semakin tersebar diseluruh Indonesia dengan angka yang sangat tinggi setiap harinya. Kepatuhan masyarakat dalam mengurangi penyebaran virus merupakan bentuk kerja sama dalam mengatasi virus corona. Wajib bagi kita masyarakat dalam mnegatasi covid - 19, dari hal di atas penulis membuat naskah publikasi tentang analisis problema pembelajaran daring terhadap pendidikan karakter peserta didik, terkhusus di masa lockdown.

Pemerintah mulai dari jajaran atas sampai ke daerah mereka memutuskan sebuah kebijakan baru yaitu dengan membuat proses pembelajaran dirumah atau biasa kita kenal dengan lockdown, lockdown digunakan agar mengurangi interaksi dengan berbagai macam orang yang bisa virus itu menyebar. (Sudarsana, 2015) kondisi new normal tidak hanya terjadi di bidang ekonomi saja tetapi juga berdampak kepada pendidikan disekolah-sekolah, belajar dari rumah (pembelajaran daring) sebagai bentuk penanggulangan dari penyebaran virus covid-19 dengan pola belajar yang dirubah dari sekolah sekarang belajar dari rumah dimana sekolah yang awalnya mereka belajar tatap muka tetapi sekarang mereka di hadapkan oleh situasi semuanya serba melalui jaringan sehingga pendidikan yang terjadi di Indonesia tidak merata dengan baik dikarekanakan ada sekolah yang tidak memiliki jaringan yang cukup kuat untuk daring terebut. Kebijakan pemerintah dengan diterapkannya belajar dari rumah.

Kebijakan pembelajaran di rumah mengakibatkan pembelajaran harus dilakukan dengan virtual atau daring. (Atiqoh, 2020) Mereka tidak bertemu dengan langsung, untuk pencegahan penularan virus corona. Walaupun terlihat bagus dan sempurna, pembelajaran daring ternyata bukanlah hal yang bisa dilakukan dengan mudah apalagi bagi merka yang tidak memiliki jaringan yang kuat untuk melaksanakan pembelajaran daring terlebih bagi sekolah yang berada didaerah pedalaman yang tidak terjangkau oleh jaringan.(Robandi and Mudjiran, 2020) ketika pembelajaran dimulai dirumah, anak-anak sangat banyak mendapat tugas dari gurunya, yang mana guru tersebut memberikan tugas setiap minggunya dan itu bertumpuk, dan peran orang tua sangat dibutuhkan sekali didalam kelas tersebut. Namun ada juga orang tua yang mengeluh dengan keadaan tersebut sehingga mereka kewalahan dalam mendampingi anak-anak mereka dalam belajar, karena mereka juga dituntut untuk bekerja demi kehidupan sehari-hari mereka sehingga anak-anak jadi terabaikan belajar dirumah dan anak-anak jadi malas dalam membuat tugas dan mereka sangat menyepelekan tugas-tugas online mereka dan menyebabkan guru-guru menjadi khawatir dengan karakter mereka nantinya (Yulianingsih et al., 2020).

Pembelajaran daring memiliki dampak yang sangat besar terhadap perubahan yang terjadi dimasyarakat, tetapi pembelajaran daring juga memiliki dampak positiv terhadap perkembangan peserta didik, (Van Bruggen, 2005) "Online learning can present challenges to educators, because the tools and opportunities for discovering students' preconceptions and cultural perspectives are often limited by bandwidth constraints that limit the view of body language and paralinguistic clues" karena pada prinsipnya pembelajran daring memberikan tantang tersendiri untuk peserta didik untuk mengembangkan potensi yang ada pada dirinya. (Winangun, 2020) karena pada dasarnya pembelajaran online sangat penting dilakukan semasa pandemi covid 19 karena situasi dan kondisi memaksa semua dilakukan dengan serba online. 
Karakter merupakan kepribadian manusia yang berhubungan dengan sang pencipta, diri pribadi, dengan lingkungannya, sebagian peserta didik karena tidak berinteraktsi dengan guru mereka menyebabkan sikap kurang patuh dari peserta didik pun terjadi, berdasarkan informasi yang peneliti dapatkan dari beberapa sekolah di kota padang, semasa pandemi ini banyak peserta didik yang mengalami perubahan karakter dan tingkah laku mereka terlebih lagi kepada guru mereka sendiri, ada peserta didik yang mengabaikan tugastugas online yang diberikan oleh guru mereka malahan ada mereka yang tidak membaca pesan WA Group terkait tugas yang diberikan dan ada juga mereka keluar dari group WA kelas mereka, permasalahan yang paling meresahkan bagi guru disekolah tersebut ada peserta didik yang melawan ketika diingatkan untuk tidak mengirim spam chat ke group, malahan ketika ditegur peserta didik tersebut mengucapkan kata-kata yang tidak pantas kepada guru mereka dan menyebabkan guru tersebut tersinggung dan kecewa.

\section{METODE PENELITIAN}

Metode dalam penelitian yang dilakukan ini merupakan review literatur atau studi pustaka. Sumber penelitian ini dari data yang dikumpulkan dari $e$-book, teks, dan sumber lain yang relevan dengan artikel yang akan dibuat yaitu problematika pembelajaran daring terhadap pendidikan karakter siswa di masa pandemi covid 19. Dalam menganalisa validitas data dilakukan analis bertahap yaitu, data yang dikumpulkan dari hasil penelitian artikel kemudian direduksi data, display data, dan yang terakhir kesimpulan data. Penelitian ini dilakukan di sekolah SMP di Kota Padang terkait dengan permasalahan yang terjadi disekolah mengenai pembelajaran daring.

\section{HASIL DAN PEMBAHASAN PENELITIAN}

Corona Virus Disease 19 (Covid-19) menyebabkan banyak dampak yang didapatkan apalagi didunia pendidikan, semua berubah terutama bagi peserta didik, mereka yang awalnya diajari oleh guru nya secara tatap muka, namun pandemi covid-19 menyebabkan semuanya dilakukan secara daring (pembelajaran daring) sehingga siswa-siswa disekolah melakukan penundaan terhadap semua pembelajaran mereka karena mereka sudah terbiasa dengan hal tersebut (Munawaroh, Alhadi and Saputra, 2017) mereka yang awalnya menunda tugas sedikit namun karena pembelajaran daring tidak ada pantauan dari guru mereka langsung sehingga mereka mejadi terbiasa dengan penundaan tugas tersebut dan ketika ditegur oleh gurunya mereka malah mengabaikan pesan tersebut.

Pembelajran daring merupakan tantangan tersendiri bagi peserta didik, (Jayul and Irwanto, 2020) proses pembelajaran merupakan proses komunikasi, yaitu proses penyampaian pesan dari sumber pesan melalui saluran/media tertentu ke penerima pesan pembelajaran daring, karena pada dasarnya proses pembelajaran merupakan suatu kombinasi yang yang tersusun meliputi unsur-unsur manusiawi, material, fasilitas, perlengkapan dan prosedur yang saling mempengaruhi mencapai tujuan pembelajaran.

Abdusshomad (2020) Pembelajaran daring ialah proses pembelajaran yang dilakukan dengan memanfaatkan berbagai fitur seperti smartphone, teknologi digital, laptop, web atau aplikasi berbasi internet atau jaringan, namun dengan pembelajaran daring ini lah banyak terjadi keluhan dari sekolah-sekolah terlebih bagi sekolah yang berada jauh dari jangkauan internet sehingga mereka susah untuk mengakses jaringan internet untuk tugas-tugas sekolah mereka. Sangat banyak siswa akan mendapatkan pengalaman baru dalam pembelajaran online ini semakin sering peserta didik tersebut belajar dan serius dalam pelajaran online maka mereka akan terbiasa dengan hal itu (Van Bruggen, 2005).

Salah satu yang menjadi dampak besar bagi pembelajaran daring ini merupakan, karakter peserta didik dimana karakter peserta didik dikarekan pembelajaran daring ini banyak berubah dan menuyebabkan guru- 
guru disekolah kewalahan dengan sikap siswa nya tersebut dan mereka jadi berani melawan guru mereka dikarenakan mereka komunikasi dengan guru mereka lewat Whatsapp dan bisa mereka mengabaikan pesan guru mereka kapan saja, dan yang menjadi permasalah ada dari peserta didik yang berani melawan guru mereka ketika memberikan informasi di group dengan kata-kata yang tidak pantas disampaikan oleh seorang murid kepada guru.

Sugeng Widodo (2013) Interaksi yang terjadi di sekolah sangat berpengaruh terhadap seorang peserta didik, namun pengaruh dari kedua orang tua jauh lebih besar terhadap diri peserta didik, dimana pandemi covid 19 mengharuskan anak-anak belajar dirumah sehingga pengaruh orang tua sangat penting untuk perkembangan diri anak tapi tidak semua orang tua yang bisa menjaga dan mengawasi anaknya ketika belajar dirumah karena rata-rata orang tua mereka ada yang bekerja dari sampai sore sehingga menyebabkan anakanak terabaikan dan anak jadi lepas kontrol dan tidak terkendali. Sejalan dengan pendapat dari (Saifulloh and Darwis, 2020) peran guru dimasa pandemi sangat dibutuhkan dalam pengelolaan pembelajaran dimulai dari Planning (perencanaan), Organizing (Pengorganisasian), Actuating (pelaksanaan) dan evaluating (evaluasi) dalam rangka meningkatkan proses belajar daring di masa pandemi covid 19 sekarang ini, baik implementasinya di dalam jaringan maupun diluar jaringan.

\section{Problema Pembelajaran Daring Terkait Pendidikan Karakter}

Berdasarkan hasil penelitian Dewi (2020) COVID-19 memiliki dampak yang sangat dalam di Pendidikan dalam memutus penularan pandemi pembelajaran yang dilakukan disekolah biasanya secara tatap muka sekarang berubah drastis menjadi serba online di berbagai macam aplikasi seperti whatsapp group. pembelajaran berjalan dengan bagus dan kreatif dalam mengasih materi terhadap siswa, dari latihan yang diberikan siswa. Namun kendala yang terjadi ada siswa yang tidak bisa mengumpulkan latihan dikarenakan ada siswa yang tidak memiliki handphone dan kurang mampu, ada juga siswa yang sengaja tidak mengirimkan tugas karena malas, dan terbiasa dengan menunda-nunda tugas yang diberikan sehingga mereka menumpuk tugas-tugas mereka di akhir semester dan tugas tersebut malah berantakan dan asal jadi saja.

Penelitian (Saleh, 2020) Pandemi global Covid 19 telah merubah gaya hidup manusia terkhusus di bidang pendidikan. Karena mengharuskan pendidikan menjadi beradaptasi cepat untuk berubah menjadi cepat dengan sistem belajar online atau bisa dikenal dengan Work From Home (WFH) di dunia pendidikan, namun kebijakan tersebut memiliki dampak yang besar terhadap perubahan diri individu terutama karakter yang menyebabkan peserta didik kurang bisa menghargai guru mereka karena ada dari mereka yang mengabaikan tugas-tugas yang diberikan oleh guru mereka.

Penelitian yang dilakukan oleh (Umairah, 2020) Pandemi covid 19 mengakibatkan tindakan pencegahan dengan meliburkan sekolah-sekolah di zona merah penyebaran Covid 19. Hal ini menyebabkan terhambatnya proses pembelajaran, guru yang biasanya mengajar dikelas menjadi kebingungan dalam memberikanproses belajar mengajar, dan salah satu cara yang dilakukan oleh guru tersebut ialah dengan via whatssapp. Namun usaha tersebut kurang bisa memotivasi peserta didik, berdasarkan analisis data diperoleh jumlah siswa yang termotivasi belajar tinggi sebanyak 17 orang, dan 1 orang yang memiliki motivasi belajar sedang.

Peneitian berikutnya (Janosik, 2020) akibat dari konsekuensi sosial di masa pandemi global covid 19 dalam bidang pendidikan adalah pengaplikasian pembelajaran jarak jauh untuk metode tunggal. Keadaan ini mengakibatkan kondisi yang tidak stabil, dan disisi lain metode ini memungkinkan diselenggarakannya pembelajaran physical distancing, dan penggunaan yang cepatdan passif mengakibatkan shock terhadap proses belajar mengajar, karena ada pembelajaran yang tidak bisa diterapkan sosial distancing, ini menyebabkan pembelajaran tersebut kurang efektif dan mengakibatkan peserta didik kurang mendalami tentang kehidupan sosial mereka di masyarakat. 
170 Analisis Problema Pembelajaran Daring Terhadap Pendidikan Karakter Peserta Didik - Harri Jumarto, Firman, Riska Ahmad

DOI : https://doi.org/10.31004/edukatif.v3i1.251

Berdasarkan penelitian Robandi and Mudjiran ( 2020 ) sistem belajar dengan daring sangat membuat siswa menajdi bingung, siswa berdampak stress, siswa menjadi bingung dan kurang kreatif dan tidak produktif, dan menyebabkan minat baca siswa menjadi lebih berukurang dikarenakan tidak adanya tekanan dari sekolah kepada siswa karena guru tidak bisa memantau siswa nya secara langsung. Karena dikatakan nilai dari pendidikan belajar online ini bisa dipakai dengan bagus oleh siswa tampa kekurangan dari arti belajar itu sendiri namun yang terjadi banyak peserta didik yang mengabaikan belajar online dan menyebabkan penurunan sikap dari peserta didik itu sendiri mereka lebih senang bermain game di HP Android mereka dan mengabaikan tugas-tugas yang diberikan oleh guru mereka.

Penelitian dari Yoga Purandina and Astra Winaya ( 2020 ) Perkembangan dari nilai karakter tersebut, ialah perubahan yang besar dalam perkembangan karakter si anak. Karakter yang baik akan menjadikan anak memiliki masa depan yang lebih cerah nantinya ketika mereka akan tumbuh dan berkembang apalagi dirumah dimana kedua orang tua terlibat dalam mengajari anaknya nilai-nilai karakter itu sendiri.

Selanjutnya penelitian dari Lusiana Siska Nurul Azizah, Nila Ispiyana ( 2020 ), Pendidikan karakter bisa ditanamkan kepada anak sejak dari lahir, mulai sewaktu kesadaran kedua orang tua membimbing dan membesarkan anak. Pendidikan karakter dilaksanakan sepenuhnya setelah diterapkan oleh kedua orang tua, semasa pandemi covid 19. Strategi yang diberikan kedua orang tua ketika menanamkan pendidikan karakter tersebut kepada anaknya, ada dua yaitu : membiasakan anak dalam belajar dengan perkembangan zaman saat ini yaitu belajar online mereka harus terbiasa dengan sistem belajar online karena kita tidak tahu kapan pandemi ini akan berakhir bisa jadi nanti pendidikan modern nantinya akan lebih memanfaatkan jaringan internet untuk belajar dan diteladania artinya peserta didik harus mampu mendalami pembelajaran lewat jaringan ini sehingga mereka tidak kaku dalam memakai teknologi dan tidak tertinggal dari perkembangan zaman. Dari strategi yang didapatkan tersebut dihasilkan pribadi anak yang disiplin, tanggung jawab dan menjadi contoh dan mandiri.

Selanjutnya penelitian (Setyorini, 2020) hasil dari penelitian tersebut adalah beberapa permasalahan yang dialami peserta didik, guru serta orang tua selama kegiatan pembelajaran daring seperti teknologi sangat kurang dan kaku dalam teknologi, dan bertambahnya biaya kuota internet, adakanya komunikasi dan sosialisasi dari kalangan guru terhadap peserta didik sehingga menyebabkan menurunnya pendampingan anak-anak. Pandemi global sangat mempengaruhi banyak kehidupan didunia pendidikan, sebagai seorang guru yang memiliki tanggung jawab untuk mendidik peserta didik tidak boleh berhenti, guru harus bisa mengelola kelas-kelas online.

Dapat kita simpulkan pembelajaran daring memiliki dampak positif dan negatif terhadap perkembangan anak, Juwita dkk ( 2020) masyrakat secara fungsional merupakan sistem yang terdiri dari bagian sosial, ketika terjadi perubahan pada suatu masyarakat, maka masyrakat lainpun juga akan mengalami perubahan dan tidak menimbulkan beberapa perilaku buruk seperti perilaku agresif, Karneli ( 2019 ) mengemukakan perilaku agresif ialah perilaku yang berupa fisik maupun verbal yang bermaksud untuk meruka atau menyakiti orang lain sehingga menyebabkan trauma bagi korban dari perilaku tersebut. Begitupula dengan pandemi covid - 19 perubahan-perubahan karakter bagi peserta didik kerap kali terjadi perubahan yang signifikan. (Purnomo and Wahyudi, 2020) nilai pendidikan karakter yang diharapkan dari peserta didik yaitu rasa menghargai perbedaan agama dan kepercayaan, berpendirian, toleransi beragama dan tidak memaksakan kehendak, dan anti perundungan.

Terjadinya penghambatan dan solusi dari pembelajaran daring tersebut sangat menarik menjadi pembahasan selama pandemi covid 19. Jamaluddin dkk, ( 2020 ) menjelaskan, kondisi guru, terhadap pembelajaran daring dapat dilakukan sedemikian rupa namun juga berpengaruh terhadap psikologi guru 
171 Analisis Problema Pembelajaran Daring Terhadap Pendidikan Karakter Peserta Didik - Harri Jumarto, Firman, Riska Ahmad

DOI : https://doi.org/10.31004/edukatif.v3i1.251

tersebut dimana mereka perlu sebuah solusi ketika terjadi penyimpangan bagi peserta didik mereka yang terdampak covid-19 karena mererka belajar secara daring.

Namun pembelajaran daring bisa menjadi modal awal bagi peserta didik untuk meningkatkan dirinya karena peserta didik dituntut untuk mandiri dikemudian hari. (Nasution, Neviyarni and Alizamar, 2017) dengan android, peserta didik bisa bertanya dengan teman tentang tugas sekolah yang rumit untuk mereka pahami, berdiskusi tentang tugas besok, memberikan kabar jika tidak bisa datang kesekolah, dan sangat banyak hal yang bisa mereka bahas dengan android. Itulah nantinya yang akan membentuk karakter peserta didik yang mandiri karena mereka juga akan di tuntut untuk berusaha demi kepentingan diri mereka pribadi.

Pendidikan karakter bagi anak merupakan catatan penting bagi seorang guru di masa sekarang ini apalagi sekarang semuanya dilakukan serba dengan teknologi, dimana menuntut seorang guru harus mengikuti perkembangan zaman, seperti yang disarankan oleh Isriwal P. A, Firman, (2019) dalam penelitiannya sebagai seorang profesional di bidangnya sangat penting bagi seorang guru untuk mengikuti perkembangan zaman karena zaman yang dihadapi tersebut akan terus berubah-rubah dan arus nya semakin cepat apalagi sekarang zaman sudah memasuki era 4.0.

\section{KESIMPULAN}

Dari pembahasan di atas dapat disimpulkan pendidikan karakter di masa pembelajaran daring sangat berubah, itu tergantung dari bagaimana seorang guru tersebut menyikapi perubahan tersebut, dimana ada peserta didik yang perubahannya semakin baik karena mereka tinggal dilingkungan keluarga yang mau membimbing mereka di masa pembelajaran daring, namun ada juga peserta didik yang sulit ketika pembelajaran daring dalam belajar sehingga karakter disiplin mereka tidak terbentuk karena mereka menundanunda bahkan ada yang tidak mengumpulkan tugas.

Berdasarkan hal itulah guru dituntut untuk mengikuti perubahan zaman, sehingga ketika semua proses belajar mengajar di daringkan guru-guru tidak panik dan mereka mempunyai bekal untuk menghadapi pembelajaran daring lebih efektif.

\section{UCAPAN TERIMA KASIH}

Terima kasih kami ucapkan kepada dosen pembimbing dan semua pihak yang terlibat dalam pembuatan artikeli ini dan membantu kelancaran artikel ilmiah ini.

\section{KESIMPULAN}

Simpulan menyajikan ringkasan dari uraian mengenai hasil dan pembahasan, mengacu pada tujuan penelitian. Berdasarkan kedua hal tersebut dikembangkan pokok-pokok pikiran baru yang merupakan esensi dari temuan penelitian.

\section{DAFTAR PUSTAKA}

Abdusshomad, A. (2020) 'Pengaruh Covid-19 terhadap Penerapan Pendidikan Karakter dan Pendidikan Islam', QALAMUNA: Jurnal Pendidikan, Sosial, dan Agama, 12(2), pp. 107-115. doi: 10.37680/qalamuna.v12i2.407.

Absor, N. F. (2020) 'Pembelajaran Sejarah Abad 21 : Tantangan dan Peluang dalam Menghadapi Pandemi Covid-19', Journal of History Education, 2(1), pp. 30-35. 
172 Analisis Problema Pembelajaran Daring Terhadap Pendidikan Karakter Peserta Didik - Harri Jumarto, Firman, Riska Ahmad

DOI : https://doi.org/10.31004/edukatif.v3i1.251

Astamal, Firman, R. (2021) 'Pembentukan Karakter Peduli Sosial pada Siswa di SMAN 3 Payakumbuh', 5, pp. 79-84.

Atiqoh, L. N. (2020) 'Respon Orang Tua Terhadap Pembelajaran Daring Pada Masa Pandemi Covid-19', Thufuli : Jurnal Ilmiah Pendidikan Islam Anak Usia Dini, 2(1), p. 45. doi: 10.33474/thufuli.v2i1.6925.

Van Bruggen, J. (2005) Theory and practice of online learning, British Journal of Educational Technology. doi: 10.1111/j.1467-8535.2005.00445_1.x.

Defi, W. F. (2020) 'Manajemen Karakter Peserta Didik Pesantren di Era Pandemi (Studi Kasus Smp Pesantren Modern Terpadu Prof. Dr. Hamka II Padang)', 21(1), pp. 1-9.

Dewi, W. A. F. (2020) 'Dampak COVID-19 terhadap Implementasi Pembelajaran Daring di Sekolah Dasar', Edukatif: Jurnal Ilmu Pendidikan, 2(1), pp. 55-61. doi: 10.31004/edukatif.v2i1.89.

Isriwal P. A, Firman, R. (2019) 'KOMPETENSI GURU: DALAM MEWUJUDKAN GENERASI BERKARAKTER DAN TERAMPIL DI ERA 4.0', 3, p. 2.

Jamaluddin, D. et al. (2020) 'Pembelajaran Daring Masa Pandemik Covid-19 Pada Calon Guru : Hambatan, Solusi dan Proyeksi', Karya Tulis Ilmiah UIN Sunan Gunung Djjati Bandung, pp. 1-10. Available at: http://digilib.uinsgd.ac.id/30518/.

Janosik, S. M. (2020) 'Membangun Efektifitas Pembelajaran Sosiologi di Tengah Pandemi Covid-19', EDUSOCIUS Jurnal Ilmiah Penelitian Pendidikan dan Sosiologi, 4(1), p. 3. Available at: https://ejournal.undiksha.ac.id/index.php/ED/article/viewFile/25073/15152.

Jayul, A. and Irwanto, E. (2020) 'Model Pembelajaran Daring Sebagai Alternatif Proses Kegiatan Belajar Pendidikan Jasmani di Tengah Pandemi Covid-19 Achmad', Jurnal Pendidikan Kesehatan Rekreasi, 6(2), pp. 190-199.

Juliya, M. and Herlambang, Y. T. (2021) 'ANALISIS PROBLEMATIKA PEMBELAJARAN DARING DAN', XII(1), pp. 281-294.

Juwita, R. et al. (2020) 'Meta Analisis: Perkembangan Teori Struktural Fungsional dalam Sosiologi Pendidikan', 3(1), pp. 1-8.

Karneli, Y. (2019) 'Upaya Guru Bk/Konselor Untuk Menurunkan Perilaku Agresif Siswa Dengan Menggunakan Konseling Kreatif Dalam Bingkai Modifikasi Kognitif Perilaku', Pedagogi: Jurnal Ilmu Pendidikan, 18(2), p. 32. doi: 10.24036/fip.100.v18i2.430.000-000.

Lusiana Siska Nurul Azizah, Nila Ispiyana, S. N. (2020) 'Strategi Orang Tua Dalam Menanamkan Pendidikan Karakter Anak Pada Masa Pandemi Covid-19’, 4(December).

Munawaroh, M., Alhadi, S. and Saputra, W. (2017) 'Tingkat Prokrastinasi Akademik Siswa Sekolah Menengah Pertama Muhammadiyah 9 Yogyakarta', Jurnal Kajian Bimbingan dan Konseling, 2(1), pp. 26-31. doi: 10.17977/um001v2i12017p026.

Nafisah, F. T. and Zafi, A. A. (2020) 'Model Pendidikan Karakter Berbasis Keluarga Perspektif Islam di Tengah Pendemi Covid-19', Ta'allum: Jurnal Pendidikan Islam, 8(1), pp. 1-20. doi: 10.21274/taalum.2020.8.1.1-20.

Nasution, J. A., Neviyarni, N. and Alizamar, A. (2017) 'Motif Siswa memiliki Smartphone dan Penggunaannya', JPPI (Jurnal Penelitian Pendidikan Indonesia), 3(2), p. 15. doi: 10.29210/02017114.

Purnomo, E. and Wahyudi, A. B. (2020) 'Nilai Pendidikan Karakter dalam Ungkapan Hikmah di SD seKaresidenan Surakarta dan Pemanfaatannya di Masa Pandemi', QALAMUNA: Jurnal Pendidikan, Sosial, dan Agama, 12(2), pp. 183-193. doi: 10.37680/qalamuna.v12i2.561.

Robandi, D. and Mudjiran, M. (2020) 'Dampak Pembelajaran Dari Masa Pandemi Covid-19 terhadap Motivasi Belajar Siswa SMP di Kota Bukittinggi', Jurnal Pendidikan Tambusai, 4(3), pp. 3498-3502. doi: $10.31004 /$ jptam.v4i3.878.

Saifulloh, A. M. and Darwis, M. (2020) 'Manajemen Pembelajaran dalam Meningkatkan Efektivitas Proses 
173 Analisis Problema Pembelajaran Daring Terhadap Pendidikan Karakter Peserta Didik - Harri Jumarto, Firman, Riska Ahmad

DOI : https://doi.org/10.31004/edukatif.v3i1.251

Belajar Mengajar di Masa Pandemi Covid-19’, Bidayatuna: Jurnal Pendidikan Guru Mandrasah Ibtidaiyah, 3(2), p. 285. doi: 10.36835/bidayatuna.v3i2.638.

Saleh, A. M. (2020) 'Problematika Kebijakan Pendidikan Di Tengah Pandemi Dan Dampaknya Terhadap Proses Pembelajaran Di Indonesia’, Jurnal Pendidikan, 2(2), pp. 24-24.

Setyorini (2020) 'Terhadap Proses Pembelajaran Pada Kurukulum 13 ?', Jiemar, 01(Juni), pp. 95-102.

Sudarsana, K. (2015) Covid -19 Perspektif Pendidikan, Acta Universitatis Agriculturae et Silviculturae Mendelianae Brunensis. Available at:

http://publications.lib.chalmers.se/records/fulltext/245180/245180.pdf\%0Ahttps://hdl.handle.net/20.500 $.12380 / 245180 \% 0$ Ahttp://dx.doi.org/10.1016/j.jsames.2011.03.003\%0Ahttps://doi.org/10.1016/j.gr.201 7.08.001\%0Ahttp://dx.doi.org/10.1016/j.precamres.2014.12.

Sugeng Widodo, A. (2013) 'Harga Diri Dan Interaksi Sosial Ditinjau Dari Status Sosial Ekonomi Orang Tua', Persona:Jurnal Psikologi Indonesia, 2(2), pp. 131-138. doi: 10.30996/persona.v2i2.100.

Umairah, P. (2020) 'Peningkatan Motivasi Belajar Menggunakan “ Google Classroom ” Ditengah Pandemi Covid-19 Pada Peserta Didik Kelas Xi Ips 4 Sman 1 Bangkinang Kota', Journal On Education, 02(03), pp. 275-285. Available at: http://www.jonedu.org/index.php/joe/article/view/319/250.

Wandari, D. and Nugraha, P. (2021) 'Pembentukan Karakter Siswa dalam pembelajaran sejarah melalui nilai kearifan lokal tradisi kenduri sko kabupaten kerinci', 5, pp. 92-95.

Winangun, I. M. A. (2020) 'Perspektif Mahasiswa terhadap Pengelolaan Pembelajaran Online dimasa Pandemi Covid-19', WIDYALAYA: Jurnal Ilmu Pendidikan, 1(1), pp. 19-27. Available at: https://jurnal.ekadanta.org/index.php/Widyalaya/article/view/69.

Yoga Purandina, I. P. and Astra Winaya, I. M. (2020) 'Pendidikan Karakter di Lingkungan Keluarga Selama Pembelajaran Jarak Jauh pada Masa Pandemi COVID-19’, Cetta: Jurnal Ilmu Pendidikan, 3(2), pp. 270-290. doi: 10.37329/cetta.v3i2.454.

Yulianingsih, W. et al. (2020) 'Keterlibatan Orangtua dalam Pendampingan Belajar Anak selama Masa Pandemi Covid-19', Jurnal Obsesi : Jurnal Pendidikan Anak Usia Dini, 5(2), pp. 1138-1150. doi: 10.31004/obsesi.v5i2.740. 